\title{
Response of Tropical African Macroinvertebrates with Varying Tolerances to Different Levels of Nitrate and Phosphate
}

\author{
Julius Daud Elias (iD \\ Tanzania Industrial Research and Development Organization (TIRDO), Environmental Division, P.O. Box 23235, \\ Dar es Salaam, Tanzania \\ Correspondence should be addressed to Julius Daud Elias; animoj@yahoo.com
}

Received 7 January 2020; Revised 10 February 2020; Accepted 21 March 2020; Published 11 July 2020

Academic Editor: Panos V. Petrakis

Copyright (c) 2020 Julius Daud Elias. This is an open access article distributed under the Creative Commons Attribution License, which permits unrestricted use, distribution, and reproduction in any medium, provided the original work is properly cited.

Acute toxicity test was performed to determine the sensitivity of Neorpela spio, Baetis harrisoni, and Tubifex spp. to nitrates $\left(\mathrm{NO}_{3}\right.$ $\mathrm{N})$ and phosphates $\left(\mathrm{PO}_{4}-\mathrm{P}\right)$ with different concentrations after 96 hours of exposure time. The observed lethal effects and/or mortality increased with concentration and exposure time among tested species of different sensitivities. The results demonstrated that both nitrate and phosphate are toxic to the three studied organisms under the test conditions, with Neorpela spio displaying the highest acute effect in water with nitrate and phosphate compared with Baetis harrisoni and Tubifex spp. The 100\% cumulative mortality was experienced at $3.2 \mathrm{mg} \mathrm{NO}-\mathrm{N} / \mathrm{L}$ and $2.4 \mathrm{mg} \mathrm{PO}_{4}-\mathrm{P} / \mathrm{L}$ for $N$. spio, $5.6 \mathrm{mg} \mathrm{NO}-\mathrm{N} / \mathrm{L}$ and $4.8 \mathrm{mg} \mathrm{PO}_{4}-\mathrm{P} / \mathrm{L}$ for $B$. harrisoni, and $128 \mathrm{mg} \mathrm{NO}_{3}-\mathrm{N} / \mathrm{L}$ and $24 \mathrm{mg} \mathrm{PO}_{4}-\mathrm{P} / \mathrm{L}$ for T. spp. However, N. spio and B. harrisoni showed high mortality at the Tanzanian nitrate recommended lower and maximum limits of 10 and $75 \mathrm{mg} \mathrm{NO}-\mathrm{N} / \mathrm{L}$, respectively, for drinking water and significant mortality at the recommended limits of nitrite $\left(20 \mathrm{mg} \mathrm{NO}_{3}-\mathrm{N} / \mathrm{L}\right)$ and phosphorus $\left(6 \mathrm{mg} \mathrm{PO}_{4}-\mathrm{P} / \mathrm{L}\right)$ concentrations for municipal and industrial wastewaters. Therefore, there is a need for these Tanzanian recommended nitrate ranges for drinking water of 10 to $75 \mathrm{mg} \mathrm{NO}_{3}-\mathrm{N} / \mathrm{L}$ and $20 \mathrm{mg} \mathrm{NO}-\mathrm{N} / \mathrm{L}$ and $6 \mathrm{mg} \mathrm{PO}_{4}-\mathrm{P} / \mathrm{L}$ for municipal and industrial wastewaters to be refined for the betterment of protecting both human health and riverine organisms.

\section{Introduction}

Nitrate and phosphate create a serious problem to freshwater macroinvertebrates when released without treatment at levels beyond recommended limits in aquatic environment $[1,2]$. While tolerance levels of a wide range of taxa have been established along gradients of organic pollution, little is known about how freshwater macroinvertebrates in tropical African regions respond to elevated levels of nitrate and phosphate [3-5]. Presence of elevated nitrate and phosphate levels in freshwater ecosystems can drive sensitive macroinvertebrate groups to extinction [3-5].

Mechanisms of toxicity vary, depending on the type and dose of toxicant compound and the type, size, and age of macroinvertebrate species exposed. Toxicological effect of nitrate and phosphate increases with increasing concentrations and exposure times [6-8]. Conversely, nitrate and phosphate effects decrease with increasing adaptability (tolerance), body size, and age of the exposed organism [7]. Nitrate and phosphate usually exhibit toxicity by transforming oxygen-carrying pigments (e.g., hemoglobin and hemocyanin) of macroinvertebrates into incapable oxygencarrying pigments (e.g., methemoglobin) $[3,6]$. In general, freshwater macroinvertebrates appear to be more sensitive to nitrate and phosphate toxicity than marine invertebrates. However, some marine macroinvertebrates are highly susceptible to nitrate and phosphate pollution and well adapted to low nitrate and phosphate concentrations at infant stage as sensitive freshwater macroinvertebrates $[3,5]$.

Despite the growing concern about the toxicological effects of nitrate and phosphate pollution in aquatic ecosystems, there are no established thresholds of harm or standard limits specifically for tropical African rivers. In Tanzania, for instance, the standard limits for surface water (rivers) are not prescribed by Tanzanian Bureau of Standards Compendium. As a result, the overenrichment problems 
associated with nitrate and phosphate pollution in rivers are underestimated and the responsible authorities dealing with freshwater quality are not fully engaged. Only nitrate standard limits for drinking water and nitrate and phosphate limits for discharged wastes from point sources were included but only for the purpose of protecting people's health and monitoring municipal and industrial wastewaters. As an effort to address the concern, this study was designed to incorporate least, moderately, and most sensitive organisms in order to provide the toxicant threshold limit ranges for protection and management efforts of riverine ecosystems. This study has therefore defined the numerical threshold limits and/or thresholds of harm as a basis in formulating Tanzanian nutrients guideline limits specifically for surface (river) water, protective for freshwater macroinvertebrates with varying tolerances. Findings of this study can be used as baseline information for water quality management in the studied area and may be replicated in other watersheds with similar agricultural activities and population scenarios.

\section{Materials and Methods}

2.1. Description of Specimen Sampling Sites. Macroinvertebrate species were sampled from Themi and Nduruma rivers located in Arusha region, the two rivers which flow into the Pangani basin lying on foothills of Mount Meru. Each river was divided into two site categories depending on river and land development, that is, reference (least impacted) and monitoring (impacted) sites. The reference sites were characterized with pristine nature and level of disturbance of the site; the monitoring sites (impacted sites) were selected based on human settlement criteria, presence of bare land, intensive grazing, and mixed peasant and large-scale farming. The two site categories (Table 1) were established in each river in which Neorpela spio, Baetis harrisoni, and Tubifex spp. were collected using kick net for toxicity test.

2.2. Selection of the Test Organisms. Since there is probably no universal and/or standard test organism(s) specifically known for toxicity testing [9-13], the selection of test organisms for this study was therefore based on (i) pollution tolerance criteria, (ii) habitat preferences and feeding habits, (iii) compatibility to and ease for use in toxicity testing, (iv) availability (diverse and/or rarity) and distribution, and (v) ecological and taxonomical relevance. The selected test organisms involved the least tolerant organisms (stonefly, Perlidae family, and N. spio), moderately tolerant organisms (mayfly, B. harrisoni), and most tolerant organisms (T. spp.).

Among the aquatic macroinvertebrates, stonefly and mayfly were chosen for this study because they are known to be relatively sensitive to changes in water quality and play an important role in the commonly used EPT Index [14]. The absence of $N$. spio and B. harrisoni at some sites found with poor water quality does imply poor water quality. N. spio was chosen as a test organism because only a few of them were counted along Tanzanian river basins, thus affirming their rarity and/or extinction due to presence of fewer reference sites. Likewise, the presence of $B$. harrisoni in both the least and moderately impacted sites and their absence in polluted downstream sites of Pangani river basin [4] point to the moderate response of the species to nutrients. Moreover, $B$. harrisoni has been mostly preferred as a test organism by the United States Environmental Protection Agency (US EPA), the American Society for Testing and Materials (ASTM) [15], and the Institute for Water Research, Grahamstown [16], in different toxicity testing. Contrary to B. harrisoni, T. spp. and Chironomidae had exhibited their tolerance as they are found dominating in impaired sites of Tanzanian river basins $[9,17]$. The ability of these organisms to inhibit and survive at sites with higher levels of human-induced pollution (extremely polluted waters of very low DO and highly turbid habitats) has therefore qualified them as test organisms representing the most tolerant organisms [18]. T. spp. and Chironomidae have been mostly preferred as test organisms by the APHA, ASTM, FAO, and US EPA in different toxicity testing protocols $[9,15,17-20]$.

2.3. Collection, Transfer, and Quarantine of Test Organisms. The least, moderately, and highly tolerant test organisms were collected from the least, moderately, and highly impacted sites, respectively, along Pangani and Wami-Ruvu river basins. The organisms of the same tolerant level were collected from the same source using kick net to avoid differences in acute sensitivities as a result of using the organisms of the same species from different sources. The organisms were collected in the field and handled properly during transportation to the laboratory for quarantine and acclimation according to ASTM E-729 [21, 22] to avoid unnecessary stress and/or injuries. During quarantine and acclimation, organisms were carefully observed daily for signs of stress, physical damage, mortality, disease, and external parasites [21]. Abnormal, dead, and injured individuals were disqualified from the test $[21,22]$. Since it was not easy to determine the exact age of test organisms, immature organisms of the same weight and length were chosen. For instance, selected instars of mayflies and stoneflies were in their early stages and $T$. spp. at their second or third instar. Immature organisms were more preferred because they are more sensitive to toxicants than older individuals of the same species $[21,22]$.

2.4. Experimental Design. Pilot toxicity test was conducted to set ranges for each compound $\left(\mathrm{NO}_{3}-\mathrm{N}\right.$ and $\left.\mathrm{PO}_{4}-\mathrm{P}\right)$ according to ASTM E-720 [17] and previously reported toxicity tests. Preliminary $\mathrm{NO}_{3}-\mathrm{N}$ and $\mathrm{PO}_{4}-\mathrm{P}$ concentration ranges of $0.4-3.2 \mathrm{mg} / \mathrm{l}$ for $N$. spio, $0.8-6.2 \mathrm{mg} / \mathrm{l}$ for $B$. harrisoni, and $2-128 \mathrm{mg} / \mathrm{l}$ for $T$. spp. were projected by the pilot test prior to testing. Static toxicity test began when test organisms were placed in treatment chambers within $30 \mathrm{~min}$ after the test material had been added into dilution water. The test organisms were exposed to two compounds $\left(\mathrm{NO}_{3}-\mathrm{N}\right.$ and $\left.\mathrm{PO}_{4}-\mathrm{P}\right)$, with different concentrations and a control (Table 2), using static and renewal procedures prescribed by ASTM E-729 [16, 17]. The selected test organisms representing the least, moderately, and most tolerant organisms 
TABLe 1: Established sites for macroinvertebrates collection along Pangani Basin.

\begin{tabular}{|c|c|c|c|c|c|c|c|}
\hline $\mathrm{S} / \mathrm{N}$. & River Name & Site Name & Latitude & Longitude & Altitude & Landform & Site category \\
\hline 1. & Themi river & Olosha & 3.20311 & 36.43261 & 1747 & Mountains & Reference \\
\hline 2. & Themi river & Lokii & 3.30349 & 36.46308 & 1085 & Plains & Monitoring \\
\hline 3. & Nduruma river & Nkoamaala & 3.19992 & 36.45367 & 1828 & Mountains & Reference \\
\hline 4. & Nduruma river & Deker Bruins & 3.24324 & 36.46941 & 1508 & Hills & Monitoring \\
\hline
\end{tabular}

TABLE 2: Number of trials undertaken during static toxicity test.

\begin{tabular}{|c|c|c|c|c|c|c|c|c|c|c|}
\hline \multirow{2}{*}{$\begin{array}{l}\text { Specimen } \\
\text { N. spio }\end{array}$} & \multirow{2}{*}{$\begin{array}{c}\text { Blanc } \\
0.0 \mathrm{mg} \\
\mathrm{NO}_{3}-\mathrm{N} / \mathrm{L} \\
0.0 \mathrm{mg} \\
\mathrm{PO}_{4}-\mathrm{P} / \mathrm{L}\end{array}$} & \multicolumn{8}{|c|}{ Concentration-based experiments } & \multirow{2}{*}{$\begin{array}{c}\text { Number of } \\
\text { treatments }\end{array}$} \\
\hline & & $\begin{array}{c}0.4 \mathrm{mg} \\
\mathrm{NO}_{3}-\mathrm{N} / \mathrm{L} \\
0.4 \mathrm{mg} \\
\mathrm{PO}_{4}-\mathrm{P} / \mathrm{L}\end{array}$ & $\begin{array}{c}0.8 \mathrm{mg} \\
\mathrm{NO}_{3}-\mathrm{N} / \mathrm{L} \\
0.8 \mathrm{mg} \\
\mathrm{PO}_{4}-\mathrm{P} / \mathrm{L}\end{array}$ & $\begin{array}{c}1.2 \mathrm{mg} \\
\mathrm{NO}_{3}-\mathrm{N} / \mathrm{L} \\
1.2 \mathrm{mg} \\
\mathrm{PO}_{4}-\mathrm{P} / \mathrm{L}\end{array}$ & $\begin{array}{c}1.6 \mathrm{mg} \\
\mathrm{NO}_{3}-\mathrm{N} / \mathrm{L} \\
1.6 \mathrm{mg} \\
\mathrm{PO}_{4}-\mathrm{P} / \mathrm{L}\end{array}$ & $\begin{array}{c}2.0 \mathrm{mg} \\
\mathrm{NO}_{3}-\mathrm{N} / \mathrm{L} \\
2.0 \mathrm{mg} \\
\mathrm{PO}_{4}-\mathrm{P} / \mathrm{L}\end{array}$ & $\begin{array}{c}2.4 \mathrm{mg} \\
\mathrm{NO}_{3}-\mathrm{N} / \mathrm{L} \\
2.4 \mathrm{mg} \\
\mathrm{PO}_{4}-\mathrm{P} / \mathrm{L}\end{array}$ & $\begin{array}{c}2.8 \mathrm{mg} \\
\mathrm{NO}_{3}-\mathrm{N} / \mathrm{L} \\
2.8 \mathrm{mg} \\
\mathrm{PO}_{4}-\mathrm{P} / \mathrm{L}\end{array}$ & $\begin{array}{c}3.2 \mathrm{mg} \\
\mathrm{NO}_{3}-\mathrm{N} / \mathrm{L} \\
3.2 \mathrm{mg} \\
\mathrm{PO}_{4}-\mathrm{P} / \mathrm{L}\end{array}$ & \\
\hline B. harrisoni & $\begin{array}{c}0.0 \mathrm{mg} \\
\mathrm{NO}_{3}-\mathrm{N} / \mathrm{L} \\
0.0 \mathrm{mg} \\
\mathrm{PO}_{4}-\mathrm{P} / \mathrm{L}\end{array}$ & $\begin{array}{c}0.8 \mathrm{mg} \\
\mathrm{NO}_{3}-\mathrm{N} / \mathrm{L} \\
0.8 \mathrm{mg} \\
\mathrm{PO}_{4}-\mathrm{P} / \mathrm{L}\end{array}$ & $\begin{array}{c}1.6 \mathrm{mg} \\
\mathrm{NO}_{3}-\mathrm{N} / \mathrm{L} \\
1.6 \mathrm{mg} \\
\mathrm{PO}_{4}-\mathrm{P} / \mathrm{L}\end{array}$ & $\begin{array}{c}2.4 \mathrm{mg} \\
\mathrm{NO}_{3}-\mathrm{N} / \mathrm{L} \\
2.4 \mathrm{mg} \\
\mathrm{PO}_{4}-\mathrm{P} / \mathrm{l}\end{array}$ & $\begin{array}{c}3.2 \mathrm{mg} \\
\mathrm{NO}_{3}-\mathrm{N} / \mathrm{L} \\
3.2 \mathrm{mg} \\
\mathrm{PO}_{4}-\mathrm{P} / \mathrm{L}\end{array}$ & $\begin{array}{c}4.0 \mathrm{mg} \\
\mathrm{NO}_{3}-\mathrm{N} / \mathrm{L} \\
4.0 \mathrm{mg} \\
\mathrm{PO}_{4}-\mathrm{P} / \mathrm{L}\end{array}$ & $\begin{array}{c}4.8 \mathrm{mg} \\
\mathrm{NO}_{3}-\mathrm{N} / \mathrm{L} \\
4.8 \mathrm{mg} \\
\mathrm{PO}_{4}-\mathrm{P} / \mathrm{L}\end{array}$ & $\begin{array}{c}5.6 \mathrm{mg} \\
\mathrm{NO}_{3}-\mathrm{N} / \mathrm{L} \\
5.6 \mathrm{mg} \\
\mathrm{PO}_{4}-\mathrm{P} / \mathrm{L}\end{array}$ & $\begin{array}{c}6.4 \mathrm{mg} \\
\mathrm{NO}_{3}-\mathrm{N} / \mathrm{L} \\
6.4 \mathrm{mg} \\
\mathrm{PO}_{4}-\mathrm{P} / \mathrm{L}\end{array}$ & 9 \\
\hline T. spp. & $\begin{array}{c}0.0 \mathrm{mg} \\
\mathrm{NO}_{3}-\mathrm{N} / \mathrm{L} \\
0.0 \mathrm{mg} \\
\mathrm{PO}_{4}-\mathrm{P} / \mathrm{L}\end{array}$ & $\begin{array}{c}2 \mathrm{mg} \\
\mathrm{NO}_{3}-\mathrm{N} / \mathrm{L} \\
2 \mathrm{mg} \\
\mathrm{PO}_{4}-\mathrm{P} / \mathrm{L}\end{array}$ & $\begin{array}{c}4 \mathrm{mg} \\
\mathrm{NO}_{3}-\mathrm{N} / \mathrm{L} \\
4 \mathrm{mg} \\
\mathrm{PO}_{4}-\mathrm{P} / \mathrm{L}\end{array}$ & $\begin{array}{c}8 \mathrm{mg} \\
\mathrm{NO}_{3}-\mathrm{N} / \mathrm{L} \\
8 \mathrm{mg} \\
\mathrm{PO}_{4}-\mathrm{P} / \mathrm{L}\end{array}$ & $\begin{array}{c}16 \mathrm{mg} \\
\mathrm{NO}_{3}-\mathrm{N} / \mathrm{L} \\
16 \mathrm{mg} \\
\mathrm{PO}_{4}-\mathrm{P} / \mathrm{L}\end{array}$ & $\begin{array}{c}24 \mathrm{mg} \\
\mathrm{NO}_{3}-\mathrm{N} / \mathrm{L} \\
24 \mathrm{mg} \\
\mathrm{PO}_{4}-\mathrm{P} / \mathrm{L}\end{array}$ & $\begin{array}{c}32 \mathrm{mg} \\
\mathrm{NO}_{3}-\mathrm{N} / \mathrm{L} \\
32 \mathrm{mg} \\
\mathrm{PO}_{4}-\mathrm{P} / \mathrm{L}\end{array}$ & $\begin{array}{c}64 \mathrm{mg} \\
\mathrm{NO}_{3}-\mathrm{N} / \mathrm{L} \\
64 \mathrm{mg} \\
\mathrm{PO}_{4}-\mathrm{P} / \mathrm{L}\end{array}$ & $\begin{array}{c}128 \mathrm{mg} \\
\mathrm{NO}_{3}-\mathrm{N} / \mathrm{L} \\
128 \mathrm{mg} \\
\mathrm{PO}_{4}-\mathrm{P} / \mathrm{L}\end{array}$ & 9 \\
\hline 3 specimens & & & & Total & number of & trials & & & & 54 \\
\hline
\end{tabular}

were separately exposed to their respective concentration ranges resulting from preliminary test for 96 hours. Ninetysix-hour static-removal toxicity test was preferred because it assumed that macroinvertebrates can survive in such duration without food.

For each compound $\left(\mathrm{NO}_{3}-\mathrm{N}\right.$ and $\left.\mathrm{PO}_{4}-\mathrm{P}\right)$, nine different concentrations were made from test solution and duplicated into 18 replicates for the three macroinvertebrate species (Table 2). A total of 54 experimental trials were performed for the two compounds (Table 2). Twenty-five individuals were subjected to each trial to maintain test organisms in good condition and avoid unnecessary stress and being crowded or subjected to rapid changes in temperature or water quality.

Water temperature change of not more than $3^{\circ} \mathrm{C}$ and dissolved oxygen concentration between 40 and 100\% were maintained throughout the test using YSI multiprobe system device (Professional Plus 6050000/ProComm 605604) every 12 hours. Because death of some invertebrates is not easily distinguished from immobilization, half maximal effective concentration $\left(\mathrm{EC}_{50}\right)$ was usually determined rather than $50 \%$ lethal concentration $\left(\mathrm{LC}_{50}\right)$. Dead and/or affected organisms in each test chamber were counted and recorded every 12 hours from the start of each test. The delayed effect tests were also determined after the experiment by placing the live test organisms in water containing no toxicant for two days.

The benchmark approach used by Cormier et al. [23] was employed on toxicity tests' findings to identify the thresholds of harm. For purposes of this study, a concentration at which mortality has just exceeded $10 \%$ was considered as minimum limit and that exceeding 50\% as maximum limit [24].
The average of recorded concentrations causing 10\% mortality for the three organism groups of different sensitivity levels and that caused just above 50\% mortality for the groups represented the ranges of threshold limits. Although this concept is still in its infancy, threshold limits were translated into standards (such as numerical limits of quantifiable stressor variables) and thus are relevant for policy-making [25].

\section{Results}

The cumulative mortalities observed from the control (blank) treatments were below 10\% for all tested macroinvertebrate groups of different sensitivity levels. Results of acute $(96 \mathrm{~h})$ toxicity responses for riverine N. spio, B. harrisoni, and $T$. spp. showed transient effects with $10 \%$ cumulative mortality at $0.8,1.6$, and $6.0 \mathrm{mg} \mathrm{NO}_{3}-\mathrm{N} / \mathrm{L}$ and 0.4 , 0.8 and $2.0 \mathrm{mg} \mathrm{PO}_{4}-\mathrm{P} / \mathrm{L}$, respectively (Figures $1-3$ ). The $100 \%$ cumulative mortality tallies were experienced at $3.2 \mathrm{mg}$ $\mathrm{NO}_{3}-\mathrm{N} / \mathrm{L}$ and $2.4 \mathrm{mg}$ PO4-P/L for N. spio, $5.6 \mathrm{mg} \mathrm{NO}-\mathrm{N} / \mathrm{L}$ and $4.8 \mathrm{mg} \mathrm{PO}_{4}-\mathrm{P} / \mathrm{L}$ for $B$. harrisoni, and $128 \mathrm{mg} \mathrm{NO}-\mathrm{N} / \mathrm{L}$ and $34 \mathrm{mg} \mathrm{PO}_{4}-\mathrm{P} / \mathrm{L}$ for $T$. spp. However, $100 \%$ cumulative mortalities that were attained by $N$. spio after being subjected to $\mathrm{LC}_{50}$ of $3.2 \mathrm{mg} \mathrm{NO}_{3}-\mathrm{N} / \mathrm{L}$ and $2.4 \mathrm{mg} \mathrm{PO}_{4}-\mathrm{P} / \mathrm{L}$ for 96 hours are considerably higher than $65 \%$ and $68 \%$ for $B$. harrisoni and $<10 \%$ for $T$. spp. One-way ANOVA revealed significant variations $(P<0.001)$ in mortalities when $N$. spio and $B$. harrisoni were subjected to different nitrate and phosphate concentrations. However, T. spp. mortalities show no variations among different nitrate and phosphate concentrations, with the $P$ values being greater than the significant value of 0.5 . 


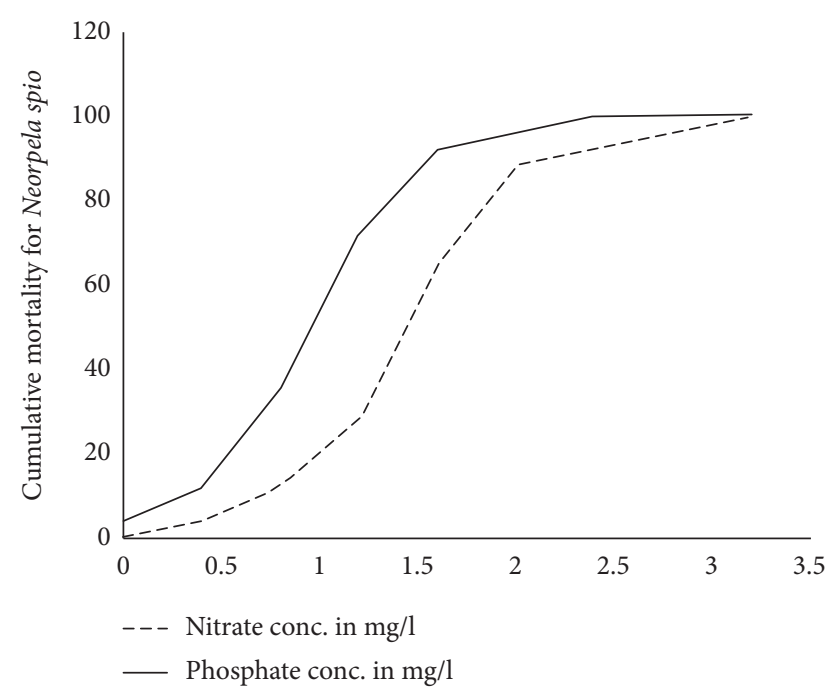

Figure 1: 96-hour concentration response curves showing cumulative mortality for N. spio.

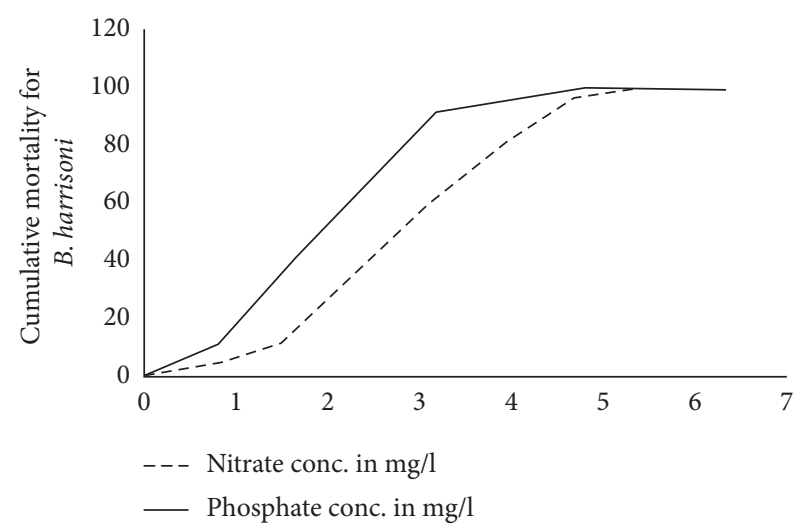

FIgURE 2: 96-hour concentration response curves showing cumulative mortality for B. harrisoni.

\section{Discussion}

Elevated nitrate and phosphate concentrations in riverine ecosystems as a result of fertilizers application in agricultural farms may result into varied toxicological consequences. Macroinvertebrate organisms, for example, are well adapted to habitats with relatively low levels of nitrate and phosphate compared with unpolluted or severely polluted habitats [5,26-28]. The resulting acute or chronic toxicity from elevated levels of phosphorus and nitrogenous compounds can impair the ability of aquatic organisms to reproduce, grow, and survive [26-29]. However, the effects of these nutrients might vary widely between the tested species with respect to their differences in nutrients' uptake, body size, developmental stage, and stress adaptation [5, 30]. Likewise, the complex relationship between a multitude of abiotic variables and community structure might obscure the effects of the toxicants, with some confounding variables tending to mask the effects of toxicants [31-33]. For instance, calcium carbonate and chloride in rivers can act as binders and thus

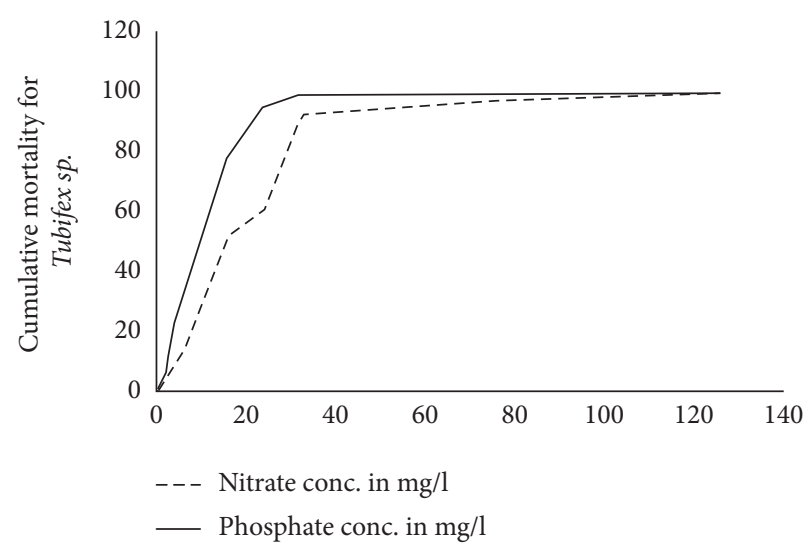

Figure 3: 96-hour concentration response curves showing cumulative mortality for $T$. spp.

decrease the effects of nitrate and phosphorus, respectively, to exposed organisms $[15,20,31,32]$.

Increased mortality tally and discrepancies observed among the tested macroinvertebrate groups are the consequences of differences in nitrate and phosphate concentrations and exposure time and sensitivity of the exposed group to toxicant. The 96-hour response curves for phosphate fall on top of nitrate (Figures 1-3), suggesting that phosphate is more harmful to tested specimens than nitrate. This indicates that $\mathrm{NO}_{3}-\mathrm{N}$ is less toxic than $\mathrm{PO}_{4}-\mathrm{P}$ to all test organisms, where T. spp. is more tolerant than $B$. harrisoni and N. spio is the least tolerant compared with B. harrisoni. These toxicity results are in line with Galdean et al. [34] who reported Plecopterans as the most vulnerable group to pollution compared with other insects. Likewise, $B$. harrisoni, which has been associated with agricultural inputs [35], is thought to be in a group with intermediate tolerant taxa in rivers impacted by agricultural activities [36] with higher tolerance than N. spio but lower than T. spp. However, stress conditions are likely to make the tested organisms more susceptible to toxicants, while the previously exposed organisms tend to build up tolerance and become less susceptible to toxicants [20]. Moreover, the combined effects of predation, intimidation by predators, and competition for food can exert distinct stress by weakening the fitness of organisms [37] and significantly increasing their vulnerability to toxicants.

With the exception of T. spp., N. spio and B. harrisoni showed $100 \%$ mortality at $3.2 \mathrm{mg} \mathrm{NO}{ }_{3}-\mathrm{N} / \mathrm{L}$ and $6.4 \mathrm{mg} \mathrm{NO}{ }^{-}$ $\mathrm{N} / \mathrm{L}$, lower than the Tanzanian nitrate recommended municipal (industrial) wastewaters limit of $20 \mathrm{mg} \mathrm{NO}-\mathrm{N} / \mathrm{L}$ and the minimum and maximum drinking water limits of 10 and $75 \mathrm{mg} \mathrm{NO}$-N/L. Similarly, $100 \%$ mortality occurred when the two species were subjected to $2.4 \mathrm{mg} \mathrm{PO}_{4}-\mathrm{P} / \mathrm{L}$ and $4.8 \mathrm{mg}$ $\mathrm{PO}_{4}-\mathrm{P} / \mathrm{L}$, lower than the recommended Tanzanian phosphate limit of $6 \mathrm{mg} \mathrm{PO}_{4}-\mathrm{P} / \mathrm{L}$ for municipal and industrial wastewaters. Therefore, there is a need for these Tanzanian recommended nitrate ranges for drinking water of 10 to $75 \mathrm{mg} \mathrm{NO}-\mathrm{N} / \mathrm{L}$ and $20 \mathrm{mg} \mathrm{NO}_{3}-\mathrm{N} / \mathrm{L}$ and $6 \mathrm{mg} \mathrm{PO}_{4}-\mathrm{P} / \mathrm{L}$ for municipal and industrial wastewaters to be refined for the 
betterment of protecting both human health and riverine organisms.

According to Cormier et al. [23] benchmark approach, limits found ranging from 0.8 to $1.2 \mathrm{mg} \mathrm{NO}_{3}-\mathrm{N} / \mathrm{L}$ for N. spio, 1.6 to $3.2 \mathrm{mg} \mathrm{NO}_{3}-\mathrm{N} / \mathrm{L}$ for $B$. harrisoni, and 6 to $16 \mathrm{mg} \mathrm{NO}_{3}-$ $\mathrm{N} / \mathrm{L}$ for T. spp., as well as 0.4 to $0.8 \mathrm{mg} \mathrm{PO}_{4}-\mathrm{P} / \mathrm{L}, 0.8$ to $2.4 \mathrm{mg}$ $\mathrm{PO}_{4}-\mathrm{P} / \mathrm{L}$, and 2 to $10 \mathrm{mg} \mathrm{PO}_{4}-\mathrm{P} / \mathrm{L}$, were calculated as threshold limits for N. spio, B. harrisoni, and T. spp., respectively. These limits are strongly supported by the thresholds of harm ranging from 2.9 to $3.6 \mathrm{mg} \mathrm{NO}_{3}-\mathrm{N} / \mathrm{L}$, to protect freshwater and marine life [38], and Camargo et al. [5] who proposed a maximum level of $2 \mathrm{mg} \mathrm{NO}-\mathrm{N} / \mathrm{L}$ for the protection of sensitive aquatic animals. Although the concept of threshold limits is still in its infancy, it can be translated into standards (such as numerical limits of quantifiable stressor variables) and thus is relevant for policy-making [25]. Therefore, the concentration ranging from 2.8 to $6.8 \mathrm{mg} \mathrm{NO}-\mathrm{N} / \mathrm{L}$ and 1.1 to $4.6 \mathrm{mg} \mathrm{PO}_{4}-\mathrm{P}$ can be suggested as the thresholds of harm to protect stream condition. Moreover, it is necessary to set threshold limits as an effort towards resource management, protection, and sustainability because it may be difficult to reverse degradation and extinction of rare species. However, it was much more difficult to detect the immediate result in acute cumulative mortality at low concentrations compared with high concentrations, where the induced high rate of acute mortality was observed easily.

\section{Conclusion}

Nitrate and phosphate are considered as pollutants to macroinvertebrate communities in freshwater ecosystems if their concentrations exceed the prescribed recommended limits. Both nitrates and phosphates have shown toxic effects on the experimented organisms, with observed mortality increasing with increased concentration and exposure time among tested species. However, N. spio and B. harrisoni showed significant mortalities when subjected to concentrations lower than the Tanzanian nitrate and phosphate recommended limits for drinking water and municipal and/or industrial wastewaters. Therefore, there is a need of refining the existing Tanzanian nitrate and phosphate recommended limits for the betterment of safeguarding human health and freshwater ecosystems. These findings can be used to guide the formulation of water quality criteria for assessing nitrate and phosphate effects in tropical African rivers.

\section{Data Availability}

The data used to support the findings of this study are available from the corresponding author upon request.

\section{Conflicts of Interest}

The authors declare that there are no conflicts of interest regarding the publication of this paper.

\section{Acknowledgments}

The authors gratefully acknowledge the Tanzania Commission for Science and Technology (COSTECH) for the financial support and Nelson Mandela African Institute of Science and Technology (NM-AIST) for their support during the field work. The authors would also like to thank the Department of Aquatic Sciences and Fisheries, University of Dar es Salaam, for providing laboratory space and facilities to analyze water and macrobenthos samples. This study received financial support from Nelson Mandela Foundation through Tanzania Commission for Science and Technology (COSTECH).

\section{References}

[1] J. A. Camargo and J. V. Ward, "Short-term toxicity of sodium nitrate (NaNO3) to non-target freshwater invertebrates," Chemosphere, vol. 24, no. 1, pp. 23-28, 1992.

[2] J. A. Camargo and J. V. Ward, "Nitrate (NO3-N) toxicity to aquatic life: a proposal of safe concentrations for two species of Nearctic freshwater invertebrates," Chemosphere, vol. 31, no. 5, pp. 3211-3216, 1995.

[3] J. A. Camargo and A. Alonso, "Ecological and toxicological effects of inorganic nitrogen pollution in aquatic ecosystems: a global assessment," Environment International, vol. 32, no. 6, pp. 831-849, 2006.

[4] B. Anderson, P. Nicely, K. Gilbert, R. Kosaka, J. Hunt, and B. Phillips, Overview of Freshwater and Marine Toxicity Tests: A Technical Tool for Ecological Risk Assessment, p. 147, California Environmental Protection Agency (Cal/EPA), Davis, CA, USA, 2004.

[5] J. A. Camargo, A. Alonso, and A. Salamanca, "Nitrate toxicity to aquatic animals: a review with new data for freshwater invertebrates," Chemosphere, vol. 58, pp. 1255-1267, 2005.

[6] G. Scott and R. L. Crunkilton, "Acute and chronic toxicity of nitrate to fathead minnows (Pimephales promelas), Ceriodaphnia dubia and Daphnia magna," Environmental Toxicology Chemistry, vol. 19, no. 12, pp. 2918-2922, 2000.

[7] S.-J. Tsai and J.-C. Chen, "Acute toxicity of nitrate on Penaeus monodon juveniles at different salinity levels," Aquaculture, vol. 213, no. 1-4, pp. 163-170, 2002.

[8] A. Alonso and J. A. Camargo, "Short term toxicity of ammonia, nitrate, and nitrite to the auatic snail Potamopyrgus antipodarum (Hyrobiidae, Mollusca)," Bulletin of Environmental Contamination Toxicology, vol. 70, no. 5, pp. 10061012, 2003.

[9] E. F. Benfield and A. L. Buikema, "Synthesis of miscellaneous invertebrate toxicity tests," in Aquatic Invertebrate Bioassays. ASTM STP 715, A. L. Buikema and J. Cairns, Eds., pp. 174187, American Society for Testing Materials, Philadelphia, Pennsylvania, 1980.

[10] S. R. Carpenter, N. F. Caraco, D. L. Correll, R. W. Howarth, A. N. Sharpley, and V. H. Smith, "Nonpoint pollution of surface waters with phosphorus and nitrogen," Ecological Applications, vol. 8, no. 3, pp. 559-568, 1998.

[11] M. J. Artal, A. Santos, B. Henry, and A. G. Umbuzeiro, "Development of an acute toxicity test with the tropical marine amphipod Parhyale hawaiensis," Ecotoxicology, vol. 27, no. 2, pp. 103-108, 2017.

[12] Standard Methods (1992), Standard Methods for the Examination of Water and Wastewater, American Public Health Association, ., Washington, DC, USA, 18th edition, 1992.

[13] A. Primbas, "Save Our Stream," 2005, http://www. saveourstream.org.

[14] J. D. Elias, J. N. Ijumba, and F. A. Mamboya, "Effectiveness and compatibility of non-tropical biomonitoring indices for 
assessing pollution in tropical rivers-a review," International Journal of Ecosystem, vol. 4, no. 3, pp. 128-134, 2014.

[15] G. D. Persoone and C. R. Jannsen, "Freshwater invertebrate toxicity tests," in Handbook of Ecotoxicology, P. Calow, Ed., pp. 51-65, Blackwell Scientific Publications, Oxford, UK, 1993.

[16] C. G. Palmer, P. A. Goetsch, and J. H. O’Keeffe, “Development of a recirculating artificial stream system to investigate the use of macroinvertebrates as water quality indicators," p. 185, Water Research Commission, Pretoria, South Africa, 1996.

[17] ASTM, "Estimating the hazard of chemical substances to aquatic life," in Special Technical Publication No. 657, J. Cairns, K. L. Dickson, and A. W. Maki, Eds., p. 264, West Conshohocken, PA, USA, 1978.

[18] B. L. Peckarsky, P. R. Fraissinet, M. A. Penton, and D. J. Conklin, Freshwater Macroinvertebrates of Northeastern North America, ISBN: 0-8014-9688-8, p. 12442, Cornell University Press, Ithaca, NY, USACornell University Press, 1990, ISBN: 0-8014-9688-8.

[19] A. L. Buikema, B. R. Niederlehner, and J. Cairns, "Biological monitoring. Toxicity testing," Water Research, vol. 16, no. 3, pp. 239-262, 1982.

[20] G. M. Rand and S. R. Petrocelli, Fundamentals of Aquatic Toxicology, p. 42, Hemisphere, New York, NY, USA, 1985.

[21] ASTM E729-96 (2002), Standard Guide for Conducting Acute Toxicity Tests on Test Materials with Fishes, Macroinvertebrates, and Amphibians, p. 22, ASTM International, West Conshohocken, PA, USA, 2002.

[22] ASTM E729-96 (2007), Standard Guide for Conducting Acute Toxicity Tests on Test Materials with Fishes, Macroinvertebrates, and Amphibians, ASTM International, West Conshohocken, PA, USA, 2007.

[23] S. M. Cormier, J. F. Paul, R. L. Spehar, P. Shaw-Allen, W. J. Berry, and G. W. Suter, "Using field data and weight of evidence to develop water quality criteria," Integrated Environmental Assessment and Management, vol. 4, no. 4, pp. 490-504, 2008.

[24] W. K. Dodds, W. H. Clements, K. Gido, R. H. Hilderbrand, and R. S. King, "Thresholds, breakpoints, and nonlinearity in freshwaters as related to management," Journal of the North American Benthological Society, vol. 29, no. 3, pp. 988-997, 2010.

[25] T. Andersen, J. Carstensen, E. Hernandez-Garcia, and C. M. Duarte, "Ecological thresholds and regime shifts: approaches to identification," Trends in Ecology and Evolution, vol. 24, no. 1, pp. 49-57, 2009.

[26] R. G. Wetzel, Limnologyp. 1006, 3rd edition, Academic Press, New York, NY, USA, 2001.

[27] M. Constable, M. Charlton, F. Jensen, K. McDonald, G. Craig, and K. W. Taylor, "An ecological risk assessment of ammonia in the aquatic environment," Human and Ecological Risk Assessment, vol. 9, no. 2, pp. 527-548, 2003.

[28] F. B. Jensen, "Nitrite disrupts multiple physiological functions in aquatic animals," Comparative Biochemistry and Physiology, vol. 135, no. 1, pp. 9-24, 2003.

[29] S. Philips, H. J. Laanbroek, and W. Verstraete, "Origin causes and effects of increased nitrite concentrations in aquatic environments," Reviews in Environmental Science and Biotechnology, vol. 1, no. 2, pp. 115-141, 2001.

[30] J. D. Rouse, C. A. Bishop, and J. Struger, "Nitrogen pollution. an assessment of its threat to amphibian survival," Environmental Health Perspectives, vol. 107, no. 10, pp. 799-803, 1999.

[31] M. Liess and R. Schulz, "Linking insecticide contamination and population response in an agricultural stream,"
Environmental Toxicology and Chemistry, vol. 18, no. 9, pp. 1948-1955, 1999.

[32] M. Liess, R. B. Schäfer, and C. A. Schriever, "The footprint of pesticide stress in communities. Species traits reveal community effects of toxicants," Science of the Total Environment, vol. 406, no. 3, pp. 484-490, 2008.

[33] A. Liess, S. Drakare, and M. Kahlert, "Atmospheric nitrogendeposition may intensify phosphorus limitation of shallow epilithic periphyton in unproductive lakes," Freshwater Biology, vol. 54, no. 8, pp. 1759-1773, 2009.

[34] N. Galdean, M. Callisto, and F. A. R. Barbosa, "Lotic ecosystem of Serra do Cipó, South east Brazil: water quality and a tentative classification based on the benthic macroinvertebrate community," Aquatic Ecosystem Health and Management, vol. 3, no. 4, pp. 545-552, 2000.

[35] J. G. Rae, "Chironomid midges as indicators of organic pollution in the Scioto river basin, Ohio," The Ohio Journal of Science, vol. 89, no. 1, pp. 5-9, 1989.

[36] M. L. Stone, M. R. Whiles, and J. D. Reeve, "Macroinvertebrate communities in agriculturally impacted southern Illinois streams: patterns with riparian vegetation, water quality, and in-stream habitat quality," Journal of Environmental Quality, vol. 34, no. 3, pp. 907-917, 2005.

[37] D. I. Bolnick and E. L. Preisser, "Resource competition modifies the strength of trait-mediated predator-prey interactions: a meta-analysis," Ecology, vol. 86, no. 10, pp. 2771-2779, 2005.

[38] Canadian Council of Ministers of the Environment, Canadian Water Quality Guidelines for the Protection of Aquatic Life: Nitrate Ion, p. 146, CCMI, Winnipeg, Canada, 2003. 